University of Nebraska - Lincoln

DigitalCommons@University of Nebraska - Lincoln

Nebraska Game and Parks Commission -- Staff

Research Publications

Nebraska Game and Parks Commission

2011

\title{
Effects of Surrounding Land Use on Playa Inundation Following Intense Rainfall
}

\author{
Alison B. Cariveau \\ Rocky Mountain Observatory, Alison.Cariveau@gmail.com \\ David C. Pavlacky Jr. \\ Rocky Mountain Observatory \\ Andrew A. Bishop \\ U.S. Fish and Wildlife Service \\ Theodore G. LaGrange \\ Nebraska Game and Parks Commission
}

Follow this and additional works at: https://digitalcommons.unl.edu/nebgamestaff

Cariveau, Alison B.; Pavlacky, David C. Jr.; Bishop, Andrew A.; and LaGrange, Theodore G., "Effects of Surrounding Land Use on Playa Inundation Following Intense Rainfall" (2011). Nebraska Game and Parks Commission -- Staff Research Publications. 56.

https://digitalcommons.unl.edu/nebgamestaff/56

This Article is brought to you for free and open access by the Nebraska Game and Parks Commission at DigitalCommons@University of Nebraska - Lincoln. It has been accepted for inclusion in Nebraska Game and Parks Commission -- Staff Research Publications by an authorized administrator of DigitalCommons@University of Nebraska - Lincoln. 


\title{
Effects of Surrounding Land use on Playa Inundation following Intense Rainfall
}

\author{
Alison B. Cariveau • David C. Pavlacky Jr. • \\ Andrew A. Bishop • Theodore G. LaGrange
}

This article is a U.S. government work, and is not subject to copyright in the United States.

Received: 24 February 2010 /Accepted: 29 November 2010 /Published online: 13 January 2011

(C) Society of Wetland Scientists 2011

\begin{abstract}
Many isolated wetlands that fill by rainfall, such as playas, have been affected by sedimentation in heavily modified agricultural landscapes. Conservation plantings and buffers reduce sedimentation in wetlands but also may reduce the frequency of inundation. We studied the effects of surrounding landcover on the responses of playas in southwestern Nebraska to heavy rain events using aerial photography, ground surveys, and GIS landscape analyses. Using a generalized linear mixed model, we found that playas in rangeland were more likely to become inundated than playas in cropland, and both were more likely to become inundated than playas in fields enrolled in USDA's Conservation Reserve Program (CRP), typified by tall, dense grasses. Inundation was also positively related to rainfall amount and playa size. Our results highlight the significance of maintaining playas in native prairie and underscore the importance of planting and managing appropriate mixes of native shortgrass and/or mixed-grass prairie species surrounding playas to mimic the vegetative structure of native prairie. In light of historic wetland losses, a reduction in the probability of flooding for
\end{abstract}

A. B. Cariveau $(\square) \cdot$ D. C. Pavlacky Jr.

Rocky Mountain Bird Observatory,

14500 Lark Bunting Lane, PO Box 1232, Brighton, CO 80603,

USA

e-mail: Alison.Cariveau@gmail.com

A. A. Bishop

United States Fish and Wildlife Service,

Rainwater Basin Joint Venture,

2550 N. Diers Ave. Suite L,

Grand Island, NE 68801, USA

T. G. LaGrange

Nebraska Game and Parks Commission,

P.O. Box 30370, Lincoln, NE 68503, USA individual playas in CRP must be weighed against the protection from sedimentation that buffers afford wetlands in cropland and other beneficial influences of CRP in the landscape.

Keywords Conservation Reserve Program · Herbaceous buffer · Hydrology · Infiltration · Nebraska · Runoff ·

Sedimentation

\section{Introduction}

Playas are shallow seasonal wetlands of the short- and mixedgrass regions of the Great Plains that become inundated after heavy rainfall events (Bolen et al. 1989; Smith 2003). Playas provide important wetland functions, including flood mitigation, capturing and filtering surface runoff, recharging the Ogallala aquifer, and enhancing biodiversity (Haukos and Smith 1994; Pezzolesi et al. 1998; Smith 2003). Characteristic wet-dry cycles produce rich vegetative and insect resources for migrating waterfowl, shorebirds, and other wetland-dependent species (Davis and Smith 1998; Haukos et al. 2006; Baar et al. 2008). Embedded in agricultural landscapes, sedimentation is considered the primary threat to playa persistence (Luo et al. 1997), with an estimated $70 \%$ of playas degraded due to sedimentation (Smith 2003). Sedimentation effects may be reduced by planting grassland buffers surrounding wetlands in farmed landscapes (Skagen et al. 2008) using soil conservation programs such as the United States Department of Agriculture's (USDA) Conservation Reserve Program (CRP). However, the thick vegetation often associated with conservation plantings and buffers can decrease overland flows, as has been found in prairie pothole wetlands (Euliss and Mushet 1996; van der Kamp et al. 2003; Detenbeck et al. 2002). This creates a potential 
conservation dilemma: conservation plantings and buffers intended to reduce sedimentation also may reduce the frequency of inundation due to capture of surface runoff or higher infiltration rates (Melcher and Skagen 2005; Skagen et al. 2008). While studies of flow rates in experimental settings are quite informative (Van Dijk et al. 1996; Abu-Zreig et al. 2004), landscape studies employing empirical data enable us to study multiple factors associated with wetland inundation. We studied the responses of playas to heavy rain events in southwestern Nebraska using aerial photography, ground surveys, and Geographic Information System (GIS) analyses. Our main objective in this study was to determine the effect of dominant surrounding landcover on playa inundation.

\section{Methods}

\section{Study Area}

The study took place in the Southwest Playa Wetland Complex (see Fig. 1) of southwestern Nebraska (LaGrange 2005), encompassing $14,385 \mathrm{~km}^{2}$ within the South-Central Semi-Arid Prairie Ecoregion (Commission for Environmental Cooperation 1997). This region consists of flat to gently rolling topography, with infrequent canyons and sand-sage hills. The dominant native vegetation is shortgrass and mixed-grass prairie composed of blue grama (Bouteloua gracilis), buffalo grass (Buchloe dactyloides), and western wheatgrass (Pascopyrum smithii). Irrigated and dry-land agriculture and livestock grazing are the primary land uses. Elevation ranges from $900 \mathrm{~m}$ to $1,650 \mathrm{~m}$, mean monthly temperature from $-4^{\circ} \mathrm{C}$ to $24^{\circ} \mathrm{C}$ and annual precipitation ranges from $38 \mathrm{~cm}$ to $51 \mathrm{~cm}$ (Birdsall and Florin 1998).

\section{Playa Dataset}

We defined playas following Smith (2003) as clay-lined, shallow, depressional recharge wetlands formed through wind, wave, and/or dissolution processes, each contained within its own watershed. The clay fraction of playa basin soils usually exceeds $50 \%$, frequently $>80 \%$ at the playa center (Smith 2003). By definition, playas only receive water from precipitation and runoff, and in this region, playas are typically temporary or seasonal, some with dry periods that can extend for years.

To map ephemeral wetlands such as playas, previous efforts have successfully located greater numbers of these wetlands by combining data sources such as National Wetlands Inventory (NWI; USFWS 1982) with soils surveys, satellite imagery, and aerial photography (e.g., Guthery and Bryant 1982; Tiner 2005; Dick and McHale 2007; Bowen et al. 2009, 2010). To make a dataset of possible playa locations, we worked with the Playa Lakes Joint Venture (PLJV) and the United States Fish and Wildlife Service (USFWS) to combine several data sources into a GIS dataset $(n=15,812)$. We began with NWI data, from which we included seasonal or temporary palustrine wetlands and excluded riverine systems and wetlands created by dams. Secondly, because most playas have clay soils in their basins we identified additional potential playa locations by finding hydric playa soils in the Soil Survey Geographic Database (SSURGO, USDA 1995). In Nebraska, Scott and Lodgepole soils were identified as the hydric soils most commonly underlying playas (LaGrange et al. 2005). Third, we incorporated playas identified in Landsat satellite imagery from wet periods between 1986 and 2000 (Ducks Unlimited, Inc 2003). Water was identified by using a wetness index distinguishing an infrared band from a visible green band, and all features less than 0.4 ha in size were removed. Playas were distinguished from other features by applying a functional definition of "surficially isolated" wetlands. Water features that intersected with the "route.drain" file (e.g., streams, rivers, canals) from the National Hydrography Dataset (USGS 2000) were removed. Playas in this cumulative probable inventory were then validated through a photo-interpretation process. This review was completed at the 1:5000 scale using the National Aerial Imagery Program (NAIP) 2-m resolution imagery (USDA Farm Service Agency (FSA) Aerial Photography Field Office (APFO) 2006a). Non-playas were removed, as identified by association with rivers, streams, dams, water treatment plants, or other structures. Occasionally, additional polygons were identified through review of the NAIP or the color infrared (CIR) imagery derived from aerial flights conducted for this study. Finally, we added a small number of locations identified during fieldwork, when those locations matched wetland footprints in the imagery; field locations taken with a Global Positioning System (GPS) were related to NAIP imagery and then playas were drawn using editing tools in ArcGIS 9.1 (ESRI 2005).

\section{Rainfall Monitoring and Aerial Surveys}

To identify areas of heavy rainfall appropriate for aerial flight surveys, we monitored daily rainfall using the National Weather Service (NWS) Gridded Rainfall Data (http://www. srh.noaa.gov/rfcshare/precip_analysis_new.php). We selected flight areas that experienced greater than $5 \mathrm{~cm}$ rainfall within $24 \mathrm{~h}$ or greater than $10 \mathrm{~cm}$ within a week; these areas also needed to encompass a minimum of 40 potential playa locations distributed within cropland, rangeland, and planted grassland (e.g., Conservation Reserve Program) cover types.

The first heavy rain event occurred on 8 August 2006, when $5-10 \mathrm{~cm}$ of rain fell in $48 \mathrm{~h}$, over an area covering 
Fig. 1 Map indicating the study area, Southwest Playa Complex of Southwestern Nebraska; aerial survey blocks indicated by open (2006) and crosshatched (2008) boxes; and potential playa wetlands in the GIS model

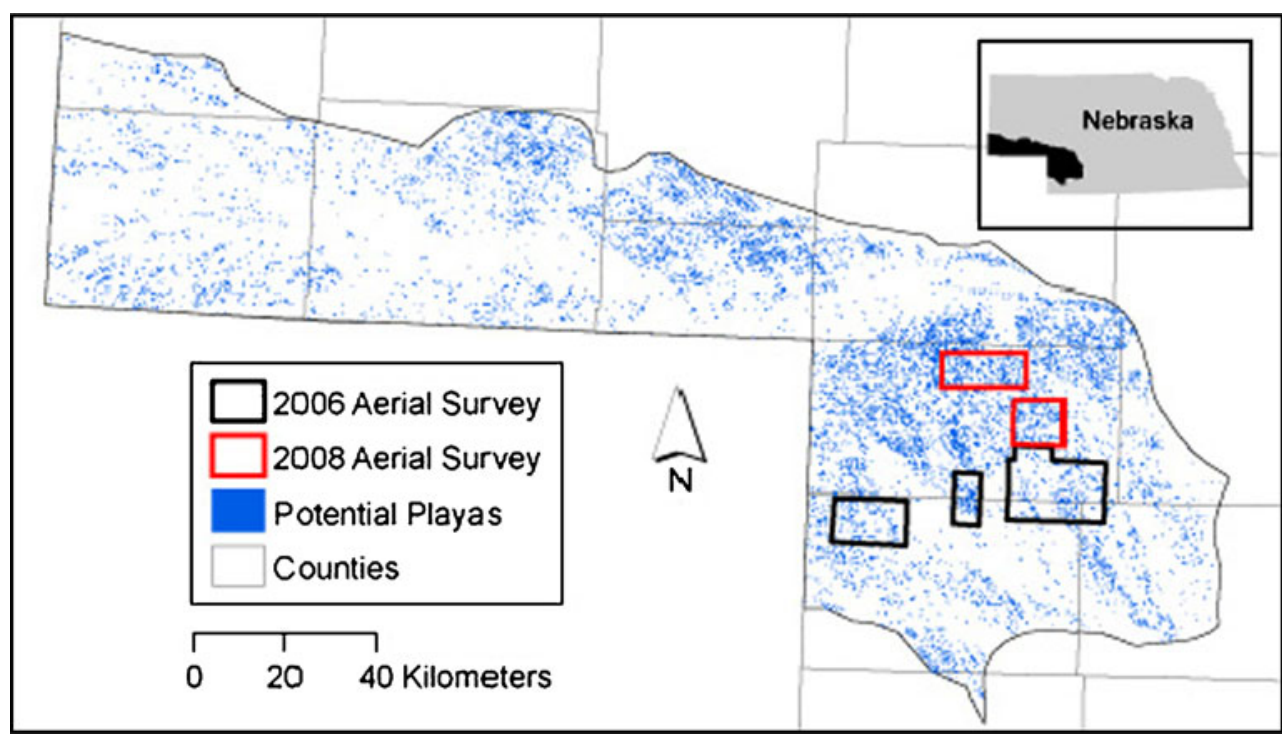

approximately $627 \mathrm{~km}^{2}$ in Chase, Hayes, and Perkins counties. On 14 August 2006, a Cessna 172 was used to obtain aerial imagery of four sample units (blocks) totaling $319 \mathrm{~km}^{2}$ (see Fig. 1) and reflecting a gradient from 3.8 to $10 \mathrm{~cm}$ of rainfall. Blocks were selected for moderate to high playa densities, to represent the rainfall gradient, and to include landcover types including cropland, planted grassland (e.g., CRP), and rangeland. The second monitored rain event occurred on 23 May 2008, when as much as $10 \mathrm{~cm}$ fell in Perkins County. On 31 May 2008, $156 \mathrm{~km}^{2}$ was flown in two blocks (Fig. 1), encompassing playas receiving 2.8-10.7 $\mathrm{cm}$ rainfall. Based upon reports from collaborators in the field, wetlands in both of these areas held no surface water prior to these two rain events. During both flights, $1-\mathrm{m}^{2}$ CIR imagery of playa basins was collected using an Applanix Trimble Digital Sensor System (DSS-439).

We estimated the amount of precipitation received at each wetland using NWS Gridded Rainfall Data $(4 \mathrm{~km}$ grid) that we compiled and summed over the days from the initial rain event through the flight date. We used the Geostatistical Analyst extension in ArcGIS (ESRI 2005) and Ordinary Kriging (Cressie 1988) to interpolate the summed Gridded Rainfall Data. We then used the Zonal Statistics Hawth's Tools extension (Beyer 2004) to estimate the mean preceding precipitation for each playa polygon. This approach allowed us to measure the total amount of precipitation received by each playa over 10 days preceding the flight, which included the heavy rainfall events described above. While interpolated for the wetland, this rainfall estimate was used to represent the rainfall in its watershed.

To assess inundation, an experienced photo-interpreter delineated the amount of ponded water visible in the CIR photography and associated it with potential playas in the GIS dataset. We estimated the percent full as proportion of the playa basin filled with water by dividing the flooded area by the area of the mapped potential playa polygon. Areas of ponded water that appeared to be playas but did not intersect a potential playa polygon were considered to be new and were added to the dataset. We calculated mean percent full for all playas in each year as well as for wet playas in each year.

\section{Local and Watershed GIS Analyses}

We estimated parameters for several variables that we expected to affect inundation, at both the local and watershed scales using ArcGIS (ESRI 2005). We determined playa size (area) as the size of the polygon in GIS, which was determined by the maximum footprint (external edge) for potential playas predicted by multiple datasets (Table 1).

To understand the effects of adjacent landcover on playa hydrology, we determined the dominant landcover type (rangeland, cropland, or CRP) for $100 \mathrm{~m}$ surrounding each playa and also at the scale of the watershed (described below; Table 1). We used the Thematic Raster Summary Hawth's Tools extension (Beyer 2004) in ArcGIS (ESRI 2005) to extract these data from the PLJV landcover layer (PLJV 2006), a compilation of various landcover data sources. Cropland and CRP coverage in the PLJV landcover were based on the Common Land Unit (CLU) layer, produced and maintained by the USDA Farm Service Agency (USDA FSA APFO 2006b). Rangeland coverage included native grassland and shrubland classes from the Ecological Systems layer for Nebraska produced by NatureServe (Comer et al. 2003). 
We were also interested in potential effects of characteristics of the playa watersheds, the areas that provide surface flows to the playas following rainfall. However, watershed sizes and boundaries could not be determined for all of the playas in the study because United States Geological Survey quadrangle maps and 10-meter digital elevation models provided insufficient topographic detail in this relatively flat environment. Therefore, we developed a predictive model of watershed sizes based on 48 playas located within our survey area for which watershed sizes were estimated by local Natural Resources Conservation Service (NRCS) personnel using GIS, topographic features, and local knowledge. Areas within watersheds that were hydrologically isolated from the playa by roads, impoundments, or other impediments were subtracted from the final watershed sizes so the watersheds reflected current drainage areas. The size of the watersheds was modeled as a function of $\log _{e}$ (Playa Hectares) using a generalized linear model with the normal distribution and log link function (PROC GENMOD, SAS Institute 2008). The resulting equation for estimating the area (ha) of playa watersheds was $\log _{e}(\mathrm{y})=$ $2.91+0.55\left[\log _{e}(\right.$ Playa Hectares $\left.)\right]$. This equation was then applied to estimate the watershed areas for the full set of playas in our study. To generate the bounding regions of playa watersheds, we used the equation for the area of a circle to calculate the radii of each playa and each watershed. We subtracted the radius of each playa from the radius of each watershed, and used the difference of the radius as the buffer distance from the edge of the playa. This produced bounding regions for playa watersheds of appropriate dimensions, assuming the watersheds were the same shape as the playa wetlands.

We estimated the relative permeability of soils in the watersheds by using the surface soil records in SSURGO (USDA 1995). The soil data were extracted using radii based on the predicted watershed size. The percentage of texture class was calculated using the area of each watershed (Table 1). Soil types were categorized into loamy (low permeability) or sandy (high permeability) types for analysis.

Table 1 Variables used in models to determine effects of surrounding landcover on inundation of playas in southwestern Nebraska. The size of each watershed was estimated as a function of playa size and the

\section{Road Surveys}

For roadside visits, we selected potential playa locations from the GIS dataset that had edges within $100 \mathrm{~m}$ of roads in the flight survey areas. We documented the relative wetness of playas by classifying the extent of standing water within the playa basin based on visual inspection. We categorized the inundation status of playas as: $>100 \%$ full, e.g., water conspicuously beyond typical basin edge; $51-100 \%$ areal extent covered by standing water; $1-50 \%$ areal extent covered by standing water; or dry. We recorded the surrounding landcover to $100 \mathrm{~m}$ around edges of the playa as cropland, CRP (typically tall-statured, planted grasslands), rangeland (typically grazed native prairie), or other. We used these field data to compare with the values derived from the aerial photography.

\section{Statistical Analyses}

We analyzed the inundation status of 1,744 playas from the 2006 and 2008 photography. To verify the accuracy of inundation assessment, we determined the concurrence of our road-based assessments of playa hydrology with interpretation of the aerial photography for 84 playas.

To estimate the probability that a playa contained ponded water, hereafter referred to as "inundated," we coded all playas that were at least $1 \%$ full as one and those that did not fill as zero. Although percent full was estimated as a continuous variable, $74 \%$ of the playas in our dataset were completely full or completely empty. The large number of $0 \%$ and $100 \%$ values precluded our use of models based on common continuous distributions, such as the normal, lognormal, or gamma distributions. Because most playas were either full or dry, and these data were not suitable for continuous distributions, we used the binomial distribution to model the inundation status of playa wetlands in this study.

The inundation status of playas was modeled as a function of covariates using a generalized linear mixed model with the binomial distribution and logit link function

bounding region of the watershed was represented by the corresponding distance from the edge of the playa

\begin{tabular}{llll}
\hline Group & Variable & Description & Range or Levels \\
\hline Precipitation & Precip & Rain $(\mathrm{cm})$ received during initial event (Aug 5-14, 2006; May 21-30, 2008) & $2.8-10.7 \mathrm{~cm}$ \\
& $\log _{e}$ (Precip) & Natural log of precipitation $(\mathrm{cm})$ at each playa during initial rainfall event & $<0.1-11.3$ ha \\
Basin & Playa size & Playa area from polygon in the GIS database & Range, Crop, CRP \\
& $\log _{e}($ Playa Size $)$ & Natural log of playa size & Range, Crop, CRP \\
& Landcover (100) & Dominant landcover type around playa to $100 \mathrm{~m}$ & $0-100 \%$ \\
Landscape & Landcover (watershed) & Dominant landcover type in the estimated watershed & Percentage of loamy soil type in the estimated watershed \\
& Loam & &
\end{tabular}


(Bolker et al. 2009; PROC GLIMMIX, SAS Institute 2008). The parameters were estimated using maximum likelihood with Adaptive Quadrature (SAS Institute 2008). We followed a sequential model building strategy that first determined the structure for the random effects and then determined the inclusion of precipitation and the local and watershed covariates (Table 1). The structure of the random effects was determined by including flight polygon, year, and flight polygon*year into the full model one at a time. After determining the structure of the random effects, we evaluated all subsets of the local variables $\left[\log _{e}\right.$ (initial precipitation), playa size, landcover (100)] and watershed variables [soil type, landcover (watershed)] (Table 1).

We used information-theoretic model selection to estimate the amount of Kullback-Liebler Information lost when models are used to approximate reality (Burnham and Anderson 2002). Akaike's Information Criteria adjusted for sample size (AICc) was used to rank the set of candidate models (Burnham and Anderson 2002). The AICc weights $\left(w_{i}\right)$ and evidence ratios were used as strength of evidence for the competing models (Burnham and Anderson 2002). We used cumulative AICc weights $\left[w_{i+}(j)\right]$ to evaluate the importance of each predictor variable (Burnham and Anderson 2002). We assessed effect sizes by evaluating the $95 \%$ confidence intervals for the parameter estimates with respect to zero. We also measured effect sizes using the odds ratio, which is the ratio of the odds of an outcome for one level of a predictor variable to the odds of that outcome for another level of the predictor variable. The odds ratio for a continuous predictor variable corresponds to an increase in the odds of an outcome per unit increase in the predictor variable. In this study, for instance, we measured effect sizes among the landcover types by calculating the ratio of the odds of an inundation event occurring in one landcover type to the odds of it occurring in another landcover type. Finally, we estimated the probability of inundation for the categorical landcover classes using the logit back transformation of the least squares means (SAS Institute 2008).

\section{Results}

In $2006,42 \%$ of playas became inundated following heavy rainfall; in $200853 \%$ became inundated. Combining years, our model included 916 inundated playas and 828 that were dry. Including dry playas, the mean percent full was 29.3 $(\mathrm{SE}=1.4)$ in 2006 and $42.9(\mathrm{SE}=1.5)$ in 2008. When depicting the percent full for only inundated playas, the means were $70.0(\mathrm{SE}=1.6)$ and $81.3(\mathrm{SE}=1.3)$ for 2006 and 2008, respectively.

Combining 40 playas from 2006 and 44 playas from 2008 that were field-visited within 11 days of the flights, we found $74 \%$ concurrence with interpretation of the aerial imagery for categories of dry, $1-50 \%$ wet, and more than $50 \%$ wet. Concurrence was $86 \%$ for whether a playa was wet or dry. We also found an overall $83 \%$ concurrence in our field characterizations of landcover when compared to the dominant adjacent landcover extracted from the PLJV Landcover.

Our analysis of the random effects indicated that flight polygon*year was the best covariance structure for the data $\left(w_{i}=1\right)$. Therefore, we included the random effect of flight*year as a covariance term in all models. The best approximating model for playa inundation in response to heavy rain contained the fixed effects of $\log _{e}$ (initial precipitation), playa size, and dominant adjacent landcover (Table 2). The estimated probability a playa would become inundated was highest for playas in rangeland $(\overline{\mathrm{x}}=0.67$, $\mathrm{SE}=0.06)$, followed by those in cropland $(\overline{\mathrm{x}}=0.49, \mathrm{SE}=$ $0.04)$; playas in ungrazed grasslands $(\overline{\mathrm{x}}=0.21, \mathrm{SE}=0.05)$ such as those in soil conservation programs (termed "CRP" hereafter) were least likely to flood (Tables 2 and 3; Fig. 2a). The odds of inundation were $87 \%$ greater in rangeland than in CRP and 53\% greater in rangeland than in cropland (Table 4). In addition, probability of inundation was positively related to amount of precipitation and playa size (Tables 2 and 3; Fig. 2b, c). The odds of inundation increased by $15 \%$ for every hectare increase in playa size (Table 4).

The second-best model of playa inundation included a positive effect for the proportion of the watershed in less permeable soils (loamy and sandy loams) (Table 2). However, the addition of the soil variable did not appreciably increase model fit as measured by the $\log$ likelihood (Table 2). The 95\% confidence interval for the effect of less permeable soils showed considerable overlap of zero $\left(\beta_{\text {Loam }}=0.002 ; 95 \% \mathrm{CI}=-0.002,0.005\right)$, which did not meet our criteria for a significant effect. There was some evidence for a model without the effect of playa size, but this model was five times less likely than the best model, which included the effect of playa size (Table 2).

The cumulative AICc weights showing the importance of the predictor variables were as follows: natural $\log _{e}$ (precipitation) (1.00), adjacent landcover (0.96), playa size (0.83), less permeable soils (0.38) and landcover (watershed) (0.04). This means that landcover(100) was 24 times $(0.96 / 0.04)$ more important than landcover(watershed) in predicting playa inundation.

\section{Discussion}

We found that dominant landcover surrounding playas in southwest Nebraska significantly affected their hydrologic function. After heavy rainfall, playas directly surrounded by 
Table 2 Model selection results for effects of precipitation, playa size, surrounding landcover, and landcover and soil permeability in the watershed on the probability of playa inundation after rain in 2006 and 2008 in southwestern Nebraska. The model selection statistics are the number of parameters $(\mathrm{K}), \log$ likelihood $[\log (L)]$, Akaike's Information Criterion corrected for sample size (AICc), AICc relative to the best model $(\triangle \mathrm{AICc})$ and $\mathrm{AICc}$ weights $\left(w_{i}\right)$. All models with $\Delta \mathrm{AICc}<10$ are shown

\begin{tabular}{|c|c|c|c|c|c|}
\hline Model & $\mathrm{K}$ & $\log (\mathrm{L})$ & $\mathrm{AICc}$ & $\Delta \mathrm{AICc}$ & $\mathrm{w}_{\mathrm{i}}$ \\
\hline $\log _{e}($ Precip $)+$ Landcover(100) + Playa size & 6 & -1094.2 & 2200.4 & 0.00 & 0.493 \\
\hline $\log _{e}($ Precip $)+$ Landcover(100) + Playa size + Loam & 7 & -1093.7 & 2201.4 & 1.00 & 0.299 \\
\hline $\log _{e}($ Precip $)+$ Landcover $(100)$ & 5 & -1096.8 & 2203.6 & 3.21 & 0.099 \\
\hline $\log _{e}($ Precip $)+$ Landcover(100) + Loam & 6 & -1096.2 & 2204.4 & 4.00 & 0.067 \\
\hline $\log _{e}($ Precip $)+$ Landcover(watershed $)+$ Playa size & 6 & -1097.4 & 2206.7 & 6.34 & 0.021 \\
\hline $\log _{e}($ Precip $)+$ Landcover(watershed $)+$ Playa size + Loam & 7 & -1096.8 & 2207.7 & 7.25 & 0.013 \\
\hline $\log _{e}($ Precip $)+$ Landcover(watershed $)$ & 5 & -1099.9 & 2209.8 & 9.35 & 0.005 \\
\hline
\end{tabular}

tall, dense, and undisturbed grasslands characterizing soil conservation programs, primarily CRP, were less likely to become inundated than farmed playas or playas in rangeland. We also found that playas in rangeland (primarily native prairie) were more likely to become inundated than playas in cropland.

In southwestern Nebraska, many of the CRP fields are planted to non-native species that are not characteristic of mixed or shortgrass prairie. These plantings have taller stature and may have greater amounts of plant litter and higher water requirements than native species. Similar effects have been noted in other wetland systems and have been postulated to apply to playas (Melcher and Skagen 2005; Skagen et al. 2008). Isolated pothole wetlands in Saskatchewan dried out after conversion of surrounding cropland to waterfowl nesting habitat dominated by brome grass and alfalfa (van der Kamp et al. 2003). In North Dakota, following heavy rainfall, the maximum depths of seasonal prairie pothole wetlands in native prairie exceeded those surrounded by buffer strips in cropland and those in watersheds planted to provide dense waterfowl nesting cover (Detenbeck et al. 2002). These effects could to be due to a higher density of vegetation impeding water flow to the wetlands as has been found experimentally with grass filter strips (Van Dijk et al. 1996; Abu-Zreig et al. 2004). van der Kamp et al. (2003) also concluded that interception of snow by the upland vegetation and greater infiltration in the dense nesting cover areas were responsible for reducing runoff to wetlands in waterfowl nesting areas.
Playas in native prairie, cropland, or in the tall, dense, and undisturbed grasslands typifying CRP in this region may differ in other ways, such as in evapo-transpiration rates that influence the natural drawdown of the wetlands. We did not measure evapo-transpiration, but differential evapo-transpiration rates could have influenced antecedent moisture condition and drawdown rates, and the wetness of playas that we observed. Due to the higher density of vegetation found in the cropland and in CRP in our study area, this likely contributed to our findings.

In addition, the landcover types we studied may differ in soil infiltration rates. Indeed, in North Dakota, native prairie and restored grassland sites had similar runoff coefficients, watershed areas, and vegetative evapotranspiration rates, supporting the conclusion that restored areas had higher infiltration rates than native prairie, presumably because of a history of tillage (Detenbeck et al. 2002). Although we did not directly test soil infiltration rates in our study, we looked for associations between mapped soil types and playa inundation. For instance, we hypothesized that CRP might be more prevalent on more erosive soils that were also more permeable. Indeed, infiltration rates have been related to soil particle size, among many other factors (Skagen et al. 2008). Luo et al. (1997) found sedimentation rates were higher for cropland playas in medium-grained soils than for those in finergrained soils. However, we were unable to demonstrate an effect of soil particle size on playa inundation in our
Table 3 Parameter estimates, standard errors (SE) and $95 \%$ confidence limits (CL) from the best approximating model for the effects of basin and watershed factors on the probability of playa inundation after rain in 2006 and 2008 in southwestern Nebraska

\begin{tabular}{lcccc}
\hline Parameter & Estimate & SE & Lower 95\% CL & Upper 95\% CL \\
\hline Intercept & -1.56 & 0.33 & -2.47 & -0.64 \\
$\log _{e}$ (Precip) & 2.28 & 0.21 & 1.86 & 2.71 \\
Playa size & 0.14 & 0.06 & 0.01 & 0.26 \\
Cropland-100 m & -0.76 & 0.19 & -1.15 & -0.38 \\
CRP-100 m & -2.04 & 0.32 & -2.68 & -1.41 \\
Range-100 m & - & - & - & - \\
Flight*Year & 0.14 & 0.10 & 0.03 & 0.71 \\
\hline
\end{tabular}


a

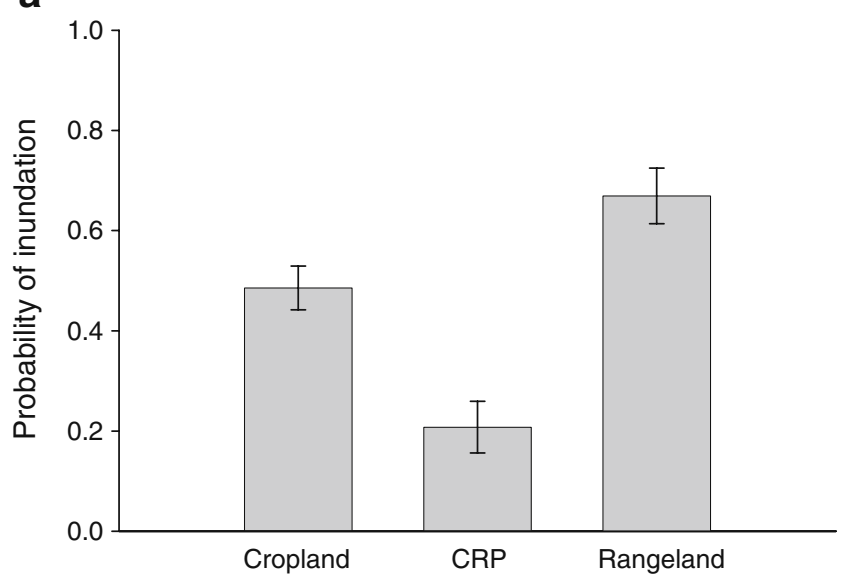

b

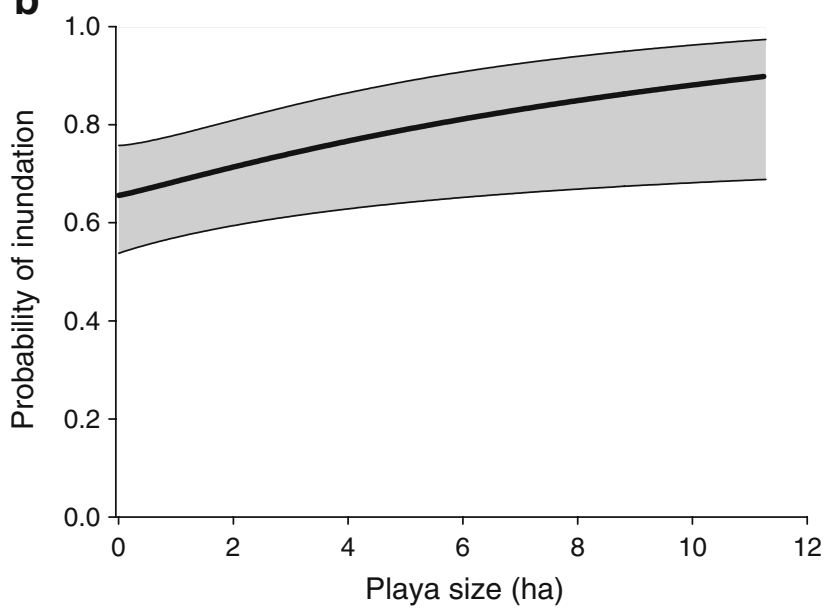

C

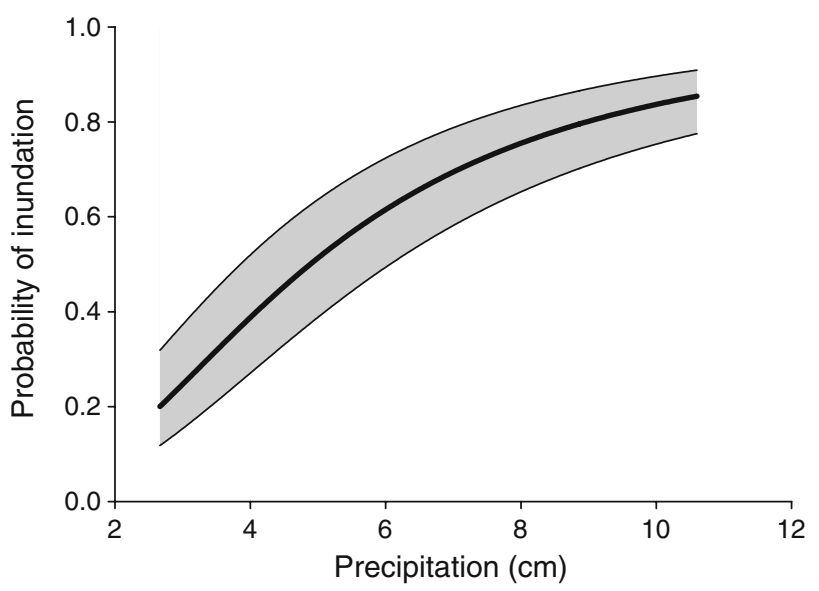

Fig. 2 The estimated probability of inundation for playas in southwest Nebraska following heavy rain as a function of a surrounding landcover type, b playa size, shown for the rangeland cover type, and $\mathbf{c}$ amount of precipitation, shown for the rangeland landcover type. The bars and bold lines represent predicted probabilities from the best approximating model. The error bars represent 1 standard error and the filled areas are $95 \%$ confidence regions
Table 4 Odds ratios and 95\% confidence limits (CL) from the best approximating model for the effects of basin and watershed factors on probability of inundation after rain in 2006 and 2008 in southwestern Nebraska. The Contrast column indicates the multiple comparisons of the odds ratio for the categorical effect of adjacent landcover

\begin{tabular}{llccc}
\hline Parameter & Contrast & $\begin{array}{l}\text { Odds } \\
\text { ratio }\end{array}$ & $\begin{array}{l}\text { Lower 95\% } \\
\text { CL }\end{array}$ & \multicolumn{2}{l}{ Upper 95\% } \\
\hline $\log _{e}$ (Precip) & & 9.80 & 6.44 & 14.92 \\
Playa size & & 1.15 & 1.01 & 1.29 \\
CRP & Cropland & 0.28 & 0.16 & 0.48 \\
Cropland & Range & 0.47 & 0.31 & 0.69 \\
CRP & Range & 0.13 & 0.06 & 0.25 \\
\hline
\end{tabular}

models, suggesting that disturbance to soils or other factors may be relatively more important. van der Kamp et al. (2003) asserted that the differences in hydrology among wetlands observed in their study were not due to soil particle size, but these data were not presented. Alternatively, our ability to detect an effect of soil type might have been reduced by modeling the extent of the playa watersheds in our study or by the coarseness of scale in the SSURGO data. Due to the paucity of studies explicitly testing the interactions between soil type and runoff, we recommend that future studies continue to consider both soils and landcover.

Our findings indicate that playas are similar to prairie pothole wetlands in that uplands in conservation programs tend to show reduced levels of runoff in comparison to native prairie sites. Our data indicated that dominant landcover at the local scale had a larger effect on playa inundation than dominant landcover at the watershed scale. This suggests that even narrow buffers of native vegetation may have an important influence on playa hydrology. Because we studied playas primarily in large tracts of planted grassland, rather than playas specifically surrounded by buffer strips, future studies should investigate how playas in various configurations of buffer habitat respond to rainfall. In addition, future work should examine the variation among buffered playas based on the seedmixes used as well as management practices applied and the stature and density of vegetation.

Sedimentation threatens the persistence of wetlands in agricultural landscapes, as evidenced in playas (Luo et al. 1997; Smith 2003; Skagen et al 2008) and prairie potholes (e.g., Gleason and Euliss 1998). Gleason and Euliss (1998) summarized the effect well, noting that sedimentation shortens the "topographical lives" of prairie pothole wetlands. Sedimentation is considered the primary threat to playas. Luo et al. (1997) estimated that playas in agricultural landscapes had lost the entirety of their wetland volume on average, in contrast to approximately one-third 
volume loss for playas in grasslands. In addition, sediments can inhibit the emergence of both invertebrates and wetland plant seeds (Gleason et al. 2003).

Erosion on cropland has declined since implementation of the Farm Bill, and wetland losses on agricultural lands have slowed during the same timeframe (NRCS 2003; Brady 2005). CRP and other soil conservation programs surely play a critical role in conserving wetlands in agricultural landscapes. Furthermore, CRP is welldocumented for providing important benefits for wildlife (Dunn et al. 1993; Best et al. 1997; Ryan et al. 1998; Heard et al. 2000; Haufler 2005), particularly nesting waterfowl (e.g., Reynolds et al. 2001; Kantrud 1993). We also found that dabbling duck and landbird abundance on playas during migration increased with the proportion of the surrounding landscape in CRP (Cariveau and Pavlacky unpublished report 2009). Birds may use CRP grasslands directly for foraging opportunities or for roosting cover, or there may be indirect effects of CRP in a landscape otherwise dominated by agriculture. For instance, Naugle et al. (1999) found Black Terns (Chlidonias niger) were more abundant in prairie pothole wetlands with more grassland surrounding them, postulating that there may have been indirect effects of grassland on the water quality and invertebrate levels in the wetlands of the area. Our finding of reduced inundation probabilities of wetlands located in conservation program areas suggest that conservation practitioners consider wetland function in project design and implementation (see also Burger 2006; Skagen et al. 2008).

\section{Management Implications}

This study highlighted the conservation significance of playas in native prairie, which had the highest probability of flooding and providing wetland conditions after heavy rainfall. Farmed playas are at risk of being filled in by sedimentation, which reduces water holding capacity and ultimately destroys playas (Luo et al. 1997; Smith 2003). Retiring these playas from farming, restoring wetland volume by removing accumulated sediments, and planting appropriate buffers around them are effective wetland conservation measures. In addition, soil conservation programs such as CRP can improve waterfowl and landbird habitat at the landscape scale. However, playas in soil conservation programs were less likely to become inundated after heavy rainfall, suggesting increased soil infiltration or taller vegetation in these areas impeded overland flow or increased evapo-transpiration. The modification of practices within the CRP could enhance the performance of this program for playa wetlands. Of critical importance is planting an appropriate mix of species native to the shortgrass and/or mixed-grass prairie. Native grass species appropriate for southwest Nebraska include native grama grasses, western wheatgrass, and buffalo grass. The addition of native forbs would also be beneficial for wildlife. In addition, disturbance of these plantings with practices used in native rangeland management, such as fire and/or grazing, could also create more natural vegetative structure. In summary, when designing and managing buffers or conservation program areas containing wetlands, conservation practitioners should mimic native prairie conditions to maximize inundation potential.

Acknowledgments The Nebraska Game and Parks Commission (NGPC) and the PLJV funded this project from the USFWS State Wildlife Grant Program and Conoco-Phillips, respectively. We thank NGPC biologists Douglas Ekberg, Mike Fritz, Tim Hermansen, Emily Munter, and Sarah Rehme; Kelsi Niederklein of Pheasants Forever; and RMBO staff Crystal Bechaver, Jennifer Blakesley, Luke Caldwell, Cliff Cordy, Derek Hill, Lacrecia Johnson, Marie-Melissa Kalamaras, Sarah Manor, Christopher Nicholson, Larry Snyder, Rob Sparks, Emily Steel, and Eric Sytsma for their hard work on this project. We thank Jacob Erdman at the USFWS Great Plains GIS Partnership and Megan McLachlan at PLJV for their assistance with aerial photography interpretation and GIS data analysis. We thank Nadine Bishop and Claudia Stevenson of the NRCS for hand-delineating playa watersheds and supporting a field surveyor, respectively. We thank Joel Jorgensen, Mike Gilbert, Tim McCoy, Ritch Nelson, and Mark Vrtiska for comments on drafts of this manuscript.

\section{References}

Abu-Zreig M, Rudra R, Lalonde M, Whitely H, Kaushik N (2004) Experimental investigation of runoff reduction and sediment removal by vegetated filter strips. Hydrological Processes 18:2029-2037

Baar L, Matlock RS, Johnson WP, Barron PB (2008) Migration chronology of waterfowl in the Southern High Plains of Texas. Waterbirds 31:394-401

Best L, Campa H, Kemp K III, Robel R, Ryan M, Savidge J, Weeks H Jr, Winterstein S (1997) Bird abundance and nesting in CRP fields and cropland in the midwest: a regional approach. Wildlife Society Bulletin 25(4):864-877

Beyer HL (2004) Hawth's Analysis Tools for ArcGIS. http://www. spatialecology.com/htools.

Birdsall SS, Florin J (1998) Regional Landscapes of the United States and Canada. Accessed online 6/5/09 at http://countrystudies.us/ united-states/geography.htm

Bolen EG, Smith LM, Schramm HL Jr (1989) Playa lakes: prairie wetlands of the Southern High Plains. Bioscience 39:615-623

Bolker BM, Brooks ME, Clark CJ, Geange SW, Poulsen JR, Stevens MHH, White JSS (2009) Generalized linear mixed models: a practical guide for ecology and evolution. Trends in Ecology and Evolution 24:127-135

Bowen KD, Beever EA, Gafvert UB (2009) Improving the design of amphibian surveys using soil data: a case study in two wilderness areas. Natural Areas Journal 29:117-125

Bowen MW, Johnson WC, Egbert SL, Klopfenstein ST (2010) A GISbased approach to identify and map Playa Wetlands on the High Plains, Kansas, USA. Wetlands 30:675-684

Brady SJ (2005) Highly Erodible Land and Swampbuster Provisions of the 2002 Farm Act in Fish and wildlife benefits of Farm Bill 
conservation programs: 2000-2005 update. The Wildlife Society Technical Review 05-2, Bethesda, Maryland, USA

Burger LW Jr (2006) Creating wildlife habitat through federal farm programs: an objective-driven approach. Wildlife Society Bulletin 34:994-999

Burnham KP, Anderson DR (2002) Model selection and multimodel inference: a practical information-theoretic approach. Springer, New York

Comer P, Faber-Langendoen D, Evans R, Gawler S, Josse C, Kittel G, Menard S, Pyne M, Reid M, Schulz K, Snow K, Teague J (2003) Ecological Systems of the United States: A Working Classification of U.S. Terrestrial Systems. NatureServe, Arlington, Virginia

Commission for Environmental Cooperation (CEC) (1997) Ecological regions of North America: toward a common perspective. CEC, Montréal, Québec

Cressie N (1988) Spatial prediction and ordinary kriging. Mathematical Geology 20:405-421

Davis CA, Smith LM (1998) Ecology and management of migrant shorebirds in the Playa Lakes Region of Texas. Wildlife Monographs 140:3-45

Detenbeck N, Elonen C, Taylor D, Cotter A, Puglisi F, Sanville W (2002) Effects of agricultural activities and best management practices on water quality of seasonal prairie pothole wetlands. Wetlands Ecology and Management 10:335-354

Dick J, McHale R (2007) Wetland and Riparian Habitats of the Playa Lakes Region: Status Report, 2006-2007. US Fish and Wildlife Service National Wetlands Inventory Program, Southwest Region 2, Albuquerque, NM

Ducks Unlimited, Inc (DU) (2003) Playa Lakes Joint Venture Geographic Information System. Ducks Unlimited, Inc, Memphis

Dunn CP, Stearns F, Guntenspergen GR, Sharpe DM (1993) Ecological Benefits of the Conservation Reserve Program. Conservation Biology 7:132-139

Environmental Systems Research Institute (ESRI) (2005) ArcGIS, version 9.1. ESRI, Redlands, California

Euliss NH Jr, Mushet DM (1996) Water-level fluctuation in wetlands as a function of landscape condition in the prairie pothole region. Wetlands 16:587-593

Gleason RA, Euliss NH Jr (1998) Sedimentation of Prairie Wetlands. Great Plains Research 8:97-112

Gleason RA, Euliss NH Jr, Hubbard DE, Duffy WG (2003) Effects of sediment load on emergence of aquatic invertebrates and plants from wetland soil egg and seed banks. Wetlands 23:26-34

Guthery FS, Bryant FC (1982) Status of playas in the Southern Great Plains. Wildlife Society Bulletin 10:309-317

Haufler JB (ed) (2005) Fish and wildlife benefits of Farm Bill conservation programs: 2000-2005 update. The Wildlife Society Technical Review 05-2, Bethesda, Maryland, USA

Haukos DA, Smith LM (1994) The importance of playa wetlands to biodiversity of the Southern High Plains. Landscape and Urban Planning 28:83-98

Haukos DA, Miller MR, Orthmeyer DL, Takekawa JY, Fleskes JP, Casazza ML, Perry WM, Moon JA (2006) Spring migration of Northern Pintails from Texas and New Mexico, USA. Waterbirds 29:127-136

Heard LP, Allen A, Best L, Brady S, Burger W, Esser A, Hackett E, Johnson D, Pederson R, Reynolds R, Rewa C, Ryan M, Molleur R, Buck P (2000) A comprehensive review of Farm Bill contributions to wildlife conservation, 1985-2000. USDA NRCS Technical Report WHMI-200, Madison, Mississippi, USA
Kantrud HA (1993) Duck nest success on Conservation Reserve Program land in the Prairie Pothole Region. Journal of Soil and Water Conservation 48(3):238-242

LaGrange TG (2005) Guide to Nebraska's wetlands and their conservation needs. Nebraska Game and Parks Commission, Lincoln, Nebraska

LaGrange TG, Thomas S, Stutheit R (2005) The geographic definitions of Nebraska's Wetland Complexes and statistics for each generated from digital National Wetland Inventory data. Nebraska Game and Parks Commission, Lincoln, Nebraska

Luo HR, Smith LM, Allen BL, Haukos DA (1997) Effects of sedimentation on playa wetland volume. Ecological Applications 7:247-252

Melcher CP, Skagen SK (2005) Grass buffers for playas in agricultural landscapes: a literature synthesis. US Department of the Interior US Geological Survey (USGS) Open File Report 2005-1220. USGS, Fort Collins, CO

Naugle DE, Higgins KF, Nusser SM, Johnson WC (1999) Scaledependent habitat use in three species of prairie wetland birds. Landscape Ecology 14:267-276

NRCS (2003) 2001 National Resources Inventory. USDA NRCS Resources Inventory Division, Washington, D.C., USA

Pezzolesi TP, Zartman RE, Fish EB, Hickey MG (1998) Nutrients in a playa wetland receiving wastewater. Journal of Environmental Quality 27:67-74

Playa Lakes Joint Venture (PLJV) (2006) Playa Lakes Regional GIS Dataset. PLJV, Lafayette, CO

Reynolds RE, Shaffer TL, Renner RW, Newton WE, Batt BDJ (2001) Impact of the conservation reserve program on duck recruitment in the US Prairie Pothole Region. Journal of Wildlife Management 65 (4):765-780

Ryan MR, Burger LW, Kurzejeski EW (1998) The impact of CRP on avian wildlife: a review. Journal of Production Agriculture 11(1):61-66

SAS Institute (2008) SAS/STAT Version 9.2. SAS Institute, Inc, Cary, North Carolina

Skagen SK, Melcher CP, Haukos DA (2008) Reducing sedimentation of depressional wetlands in agricultural landscapes. Wetlands 28:594 604

Smith LM (2003) Playas of the Great Plains. University of Texas, Austin, Texas

Tiner RW (2005) Assessing cumulative loss of wetland functions in the Nanticoke River watershed using enhanced National Wetlands Inventory data. Wetlands 25:405-419

US Department of Agriculture (USDA) (1995) Soil survey geographic database. Miscellaneous Publication 1527, USDA, National Soil Survey Center, NRCS, Fort Worth, Texas

USDA-Farm Services Agency (FSA)-Aerial Photography Field Office (APFO) (2006) 2005 Imagery_Quarter-Quadrangles-Index for the State of Nebraska. Salt Lake City, UT

USDA-FSA-APFO (2006b) Common Land Unit Data (http://origin. www.fsa.usda.gov/FSA/apfoapp?area=home\&subject=prod \& topic $=\mathrm{clu}$ ), Salt Lake City, UT

US Fish and Wildlife Service (1982) National Wetlands Inventory. US Department of the Interior, Fish and Wildlife Service, Washington, D.C. http://www.fws.gov/wetlands/

US Geological Survey (USGS) (2000) National Hydrography Dataset. USGS in cooperation with United States Environmental Protection Agency, Reston, VA

van der Kamp G, Hayashi M, Gallen D (2003) Comparing the hydrology of grassed and cultivated catchments in the semi-arid Canadian prairies. Hydrological Processes 17:559-575

Van Dijk PM, Kwaad FJ, Klapwijk M (1996) Retention of water and sediment by grass strips. Hydrological Processes 10:1069-1080 